Yu. Bederak ${ }^{1}$, D. Gapon ${ }^{2}$, A. Zuev ${ }^{2}$

${ }^{1}$ PJSC «AZOT», Cherkasy, Ukraine

${ }^{2}$ National Technical University «Kharkiv Polytechnic Institute», Kharkiv, Ukraine

\title{
METHOD OF DETERMINING THE PARAMETERS OF AN EQUIVALENT ASYNCHRONOUS ELECTRIC MOTOR IN REAL TIME
}

\begin{abstract}
A calculation of the parameters of the equivalent asynchronous electric machine allows introducing the automated calculation of the static and dynamic stability of an electrical supply system in an industrial enterprise for any combination of different electric motors. It also ensures the electromagnetic compatibility in a network by means of calculations of nonsinusoidal mode in the network with proposed sources of higher harmonics. The research purpose is a method for accurate determination of the equivalent asynchronous machine parameters for the load node consisting of several groups of asynchronous electric motors of the same type. An algorithm block diagram for calculating the initial data is developed. The input data is the number of groups of the same motor type, the number of machines in each group, and a vector of the engine power ratings. The polling of the counters of each engine in all groups is performed through the use of an embedded cycle. A fragment of a substation one-line scheme which feeds an electrical industrial enterprise water circuit is given: three $800 \mathrm{~kW}$ asynchronous machines for each pump, three $400 \mathrm{~kW}$ asynchronous machines and three $250 \mathrm{~kW}$ asynchronous machines. The calculation results for the given example of the scheme are executed and presented in the table. The data obtained show that the actual parameters of the equivalent machine in a $6 \mathrm{kV}$ load node are significantly different from the averaged data. The typical difference between the results obtained by the proposed method and the available methods is $5 \%$, and the maximum reaches $30 \%$. Therefore, it is expedient to use accurate data when performing calculations.
\end{abstract}

Keywords : equivalent asynchronous machine; group of electric motors of the same type; load node; information and control system.

\section{Introduction}

In most cases, the main load in the distribution substations of industrial undertakings is created by a group of asynchronous motors (AM). The influence of the resistance of this group on the power supply mode is enough significant to ensure the accepted accuracy of the calculations, the calculations of the equivalent resistance of several groups of motors belonging to the same type must be extremely precise.

The approximate formulas developed for the equivalent AM parameters calculation do not take into account the nameplate data for each motor. For a load node consisting of many different $0.4 \mathrm{kV}$ motors, calculating the parameters of the equivalent $\mathrm{AM}$ at any specific time with required accuracy is impossible. But for a load node consisting of several groups of $6 \mathrm{kV}$ motors of the same type this task is of immediate interest, and can be performed by using information and control systems.

The modern stage of the information processing technologies development can be described by the wide use of the information and control systems, including their use to control distribution substations. Such a system can be always used to calculate the static and dynamic stability of an industrial undertaking powersupply system for any combination of different motors. In addition, such system allows computing nonsinusoidal mode in a network with a higher harmonics source, which will ensure electromagnetic compatibility in the electric network.

Literature data analysis and the problem statement. In [1] analyzes the AM parameters calculation in different working modes, but it lacks a calculation procedure for groups consisting of several motors.
The calculation procedure given in [2] is intended for control systems and does not allow taking into account the influence of the motors working modes on an electric power system.

Generalizations made in [3] can be used only to calculate motors with a high rotating speed.

In the article [4] is the closest to solving the problem of the asynchronous motors group parameters, but the algorithm this work describes requires adjustment in order to function in a real-time scale.

The model contemplated in work [5] is not unraveled to the full extent - moreover, its practical implementation is not described, which makes it impossible to use except in the MATLAB simulation environment.

In the article [6] describes a method to estimate the AM parameters when the extent of the available data is minimal, but the obtained estimate demonstrates significant discrepancy, which prevents it from using in resonance effects calculations within an electric power system.

Thus, none of the methods considered can be used to effectively analyze the interaction of an electric power system with motors groups in real time.

Theoretical foundations for automatic systems for measurement of power consumption (ASFMOPC) have been developed in $[7,8]$. The ASFMOPC collect the energy accounting data from electricity meters (electronic meters). These data are processed by an ASFMOPC server and can be used to solve different problems, including determination of the parameters of the equivalent AM.

Thus, using the energy accounting data, which can be obtained in real time mode and transmitted for further processing in ASFMOPC, and the theory to calculate the parameters of the equivalent $\mathrm{AM}$, it is 
reasonable to determine the number of working motors in each group in real time mode. It can be used to build information and control system determining the equivalent AM parameters, which in turn can be used in automated calculations of the parameters and modes of the power-supply system for industrial undertakings.

The goal of the article consists in developing a method to determine the equivalent asynchronous motor parameters for a load node comprising several groups of similar asynchronous motors of significant power.

\section{Calculating the parameters of the equivalent AM}

Theoretical basis of the equivalent AM parameters calculation are developed completely enough by Yu.E. Gurevich in [9, 10]. Article [11] describes a method that automatically determines the number of asynchronous or synchronous motors with $10(6) \mathrm{kV}$ voltage in a group of the single-type motors. But in practice, the 10(6) $\mathrm{kV}$ buses of a substation are connected to several groups of motors, so to perform automatic calculations it is necessary to know the number of working motors in each group at any given moment.

The following nameplate data and AM groups parameters are used as the output data for equivalenting of an asynchronous motor: $P_{n}$ is the rated active power of the motor, $\mathrm{kW} ; Q_{n}$ is the rated reactive power of the motor, $\mathrm{kVAr} ; I_{n}$ is the motor rated current, $\mathrm{A} ; \cos \phi_{n}$ is the rated power factor, relative units $(\mathrm{RU}) ; k$ is the locked rotor current ratio, RU; $M_{m}$ is the ratio of the maximum torque to the rated one, $\mathrm{RU} ; M_{p}$ is the ratio of the starting torque to the rated one, $\mathrm{RU} ; w_{P i}$ is the weighting factor of the rated active power of each motor group for the total rated power of all AMs, RU.

In the expressions for the equivalent $\mathrm{AM}$ calculation, the number of the single type motors in the AM group is expressed as $n$.
According to researches [1], the no-load current of the AM $I_{i s}$ is calculated according to the following formula:

$$
I_{i s}=I_{n} \cdot\left(\sin \phi_{n}-\cos \phi_{n} /\left(b_{n}+\sqrt{b_{n}^{2}-1}\right)\right),
$$

where $b_{n}$ is the ratio of the maximum torque to the rated one on the AM shaft. Calculation made according to the AM catalogued data $\left(\cos \phi_{n}=0.8 \ldots 0.92\right.$; $b_{n}=2 \ldots 2.7$ ) show that the minimal value of $I_{i s}$ is within the interval from 25 to $40 \%$ of the motor rated current [11]. These relationships are used to determine the working state of the AM. That is why it is reasonable to determine one minimal value for the AM power upon achieving which it is considered put into operation (that is, $25 \%$ ).

Using the above mentioned information makes it possible to develop a method for automatic determination of the AM parameters in a real-time scale, which will function as part of information and control system for an industrial undertaking power supply.

\section{Determination of the equivalent AM parameters in a real-time scale in an information and control system}

Figure 1 shows a single line diagram section of a substation energizing electric users of an industrial undertaking water recirculation system (three $800 \mathrm{~kW}$ asynchronous motors to drive cold water supply pumps (CWP), three $400 \mathrm{~kW}$ asynchronous motors for hot water supply pumps (HWP), and three $250 \mathrm{~kW}$ asynchronous motors for cooling towers fan installations (FI)).

The nameplate data for each AM group and calculated parameters of the equivalent $\mathrm{AM}$ are given in Table 1.

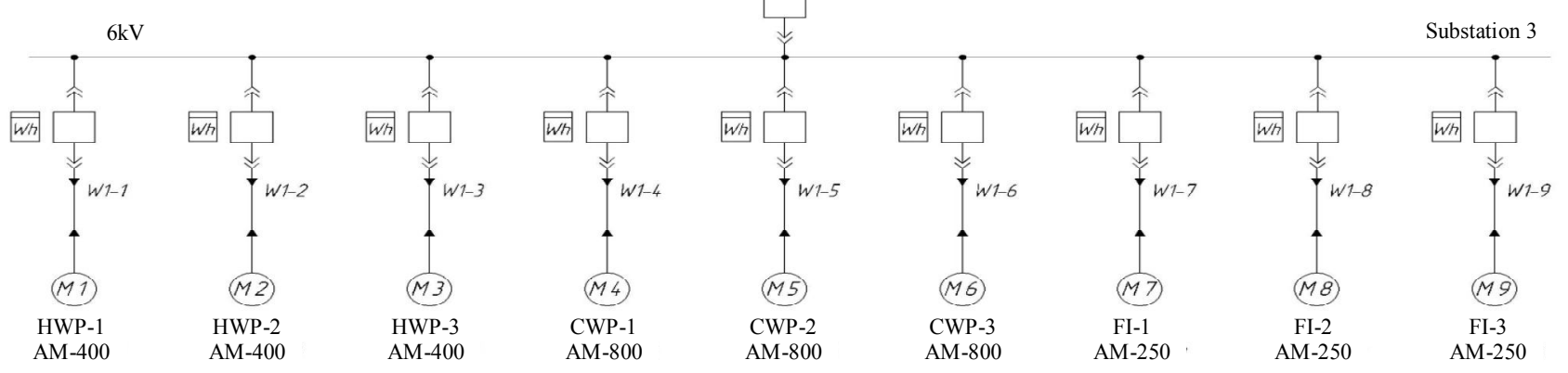

Fig. 1. A single line diagram section of a $6 \mathrm{kV}$ substation energizing the electric users of the water recirculation system

Table 1. The nameplate data and parameters of groups consisting of the same type AMs

\begin{tabular}{|l|c|c|c|c|c|c|c|c|c|c|}
\hline $\begin{array}{c}\text { AM } \\
\text { designation }\end{array}$ & AM type & $\begin{array}{c}P_{n}, \\
\mathrm{~kW}\end{array}$ & $I_{n}, \mathrm{~A}$ & $\begin{array}{c}\cos \phi_{n}, \\
\mathrm{RU}\end{array}$ & $\begin{array}{c}Q_{n}, \\
\mathrm{kVAr}\end{array}$ & $\begin{array}{c}\operatorname{tg} \phi_{n}, \\
\mathrm{RU}\end{array}$ & $\begin{array}{c}M_{m}, \\
\mathrm{RU}\end{array}$ & $\begin{array}{c}M_{n}, \\
\mathrm{RU}\end{array}$ & $\begin{array}{c}k, \\
\mathrm{RU}\end{array}$ & $\begin{array}{c}w_{P i}, \\
\mathrm{RU}\end{array}$ \\
\hline \multicolumn{1}{c|}{1} & 2 & 3 & 4 & 5 & 6 & 7 & 8 & 9 & 10 & 11 \\
\hline $\mathrm{CWP}$ & $\mathrm{A} 4-450 \mathrm{Y}-6 \mathrm{Y} 3$ & 800 & 74.5 & 0.860 & 474 & 0.593 & 2.000 & 1.00 & 5.40 & 0.552 \\
\hline HWP & $\mathrm{A} 13-42-8$ & 400 & 48.0 & 0.860 & 237 & 0.593 & 2.100 & 1.20 & 5.10 & 0.276 \\
\hline FI & $\mathrm{A} 113-4$ & 250 & 29.4 & 0.889 & 129 & 0.515 & 2.500 & 1.30 & 5.80 & 0.172 \\
\hline Equivalent AM & - & 4350 & 455.7 & 0.865 & 2520 & 0.579 & 2.055 & 1.07 & 5.38 & 1.000 \\
\hline
\end{tabular}


To determine the number of AMs (or SMs) in each group of identical electric motors, it is proposed to install electronic multifunctional electricity meters in the relay section on each connection of high-voltage motors, so as to measure the current, voltage, power, frequency and other parameters of the power supply mode in real time mode. The information system is to provide data collecting, data processing, and data transmission to ASFMOPC in real-time mode. For it to work, it is necessary to develop an algorithm that would check the measured values of the power for raw errors, and automatically calculate the number of AMs (SMs) in the groups consisting of same type electric motors. This algorithm is shown in Figure 2.

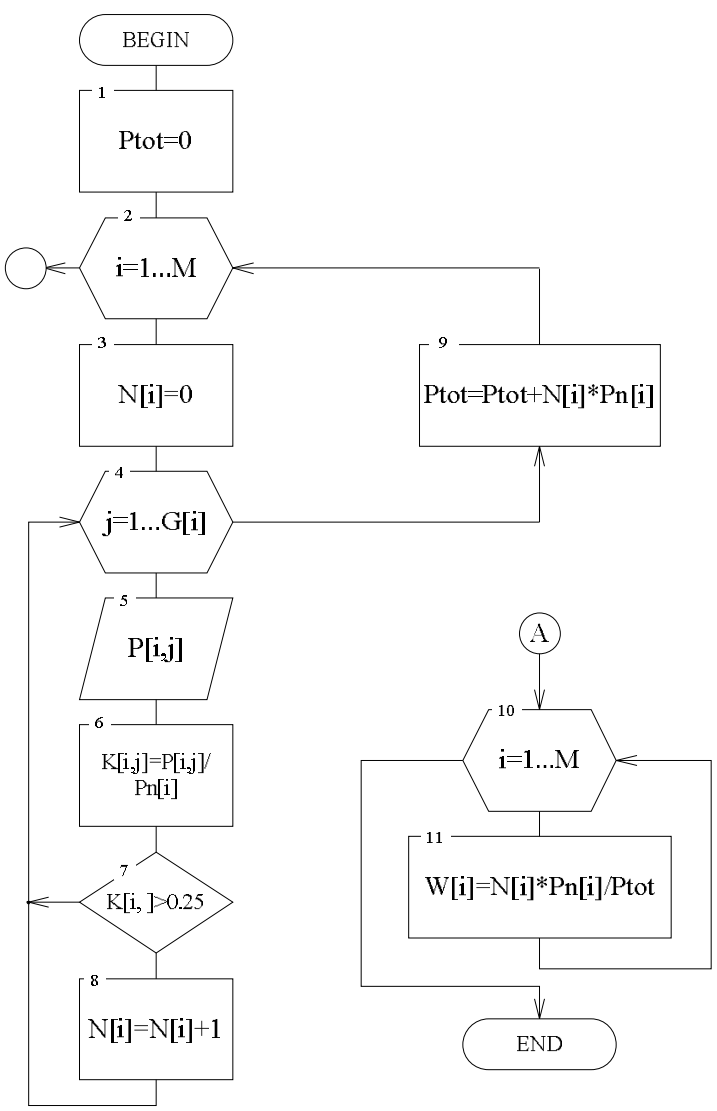

Fig. 2. The scheme of the algorithm determining the number of energized AMs (SMs)

The output data include the number of groups consisting of the same type motors $M$, the vector for the number of motors in each group $G$, and the vector of the rated powers of the motors $P_{n}$. An embedded loop is used to iterate and poll the meters of each motor in all groups. The relative power $K$ is calculated according to the known actual power being consumed. When the motors load exceeds $25 \%$ of its rated power, the motor is considered energized. In this case the value of the corresponding counter in the counters vector $N$ is incremented. The execution of the algorithm results in the complete list of the number of the energized motors for each group, saved as the vector $N$.

At the same time, the total power of the energized motors Ptot is calculated, being represented as the vector of the weight coefficients $W$ for the motors groups. The algorithm shown can be implemented by using microcontroller techniques within the boundaries of an information and control system, operating in a real-time scale.

\section{Analysis of the described method}

When analyzing a network node that energizes an AM group (or an SM group), two distinctive cases can be distinguished:

1) Few motors with known parameters and working mode are connected to this electrical network node. This case applies to medium voltage AMs with rated power from $200 \mathrm{~kW}$. The exact number of AMs can be determined by using the electricity meters connected to ASFMOPC. This increases the accuracy when determining parameters of the equivalent AM according to the approach and calculation methods are described in $[2,10,11]$. These data can be used to obtain the static stability of the AM and nonsinusoidal mode of the power-supply system with a higher harmonics source $(\mathrm{HH})$.

Let's give an example of the equivalent AM parameters calculation using the nameplate data from Table 1 and the single line diagram shown in Figure 1. At the moment, there are three CWP operating (their number being $N_{1}=3$ ), as well as three HWP $\left(N_{2}=3\right)$, and three FI $\left(N_{3}=3\right)$. The total rated active power of the equivalent $\mathrm{AM}$ is expressed as follows:

$$
\begin{aligned}
P_{n, e q} & =\sum_{i=1}^{M} N_{i} P_{n, i}=3 \cdot 800+3 \cdot 400+3 \cdot 250=4350 \mathrm{~kW}, \\
Q_{n, e q} & =\sum_{i=1}^{M} N_{i} Q_{n, i}=3 \cdot 474+3 \cdot 237+3 \cdot 129=2250 \mathrm{kVAr} .
\end{aligned}
$$

The actual value of the real power of the AMs being operated is determined according to the electricity meters. The actual reactive power of the equivalent AM is found similarly. The displacement power factor of the equivalent $\mathrm{AM} \operatorname{tg} \phi_{n, e q}$ is determined according:

$$
\operatorname{tg} \phi_{n, e q}=Q_{n, e q} / P_{n, e q} .
$$

When introducing the weighting factors $w_{P i}$ in relation to the rated active power of the each motor group $P_{n, i}$, the value of the weighting factor will be equal to the following:

$$
w_{P i}=N_{i} P_{n, i} / \sum_{j=1}^{M}\left(N_{j} P_{n, j}\right) .
$$

The substitution of values results in the following:

$$
\begin{aligned}
& w_{P 1}=\frac{3 \cdot 800}{3 \cdot 800+3 \cdot 400+3 \cdot 250}=0.552, \\
& w_{P 2}=\frac{3 \cdot 400}{3 \cdot 800+3 \cdot 400+3 \cdot 250}=0.276, \\
& w_{P 3}=\frac{3 \cdot 259}{3 \cdot 800+3 \cdot 400+3 \cdot 250}=0.172 .
\end{aligned}
$$

Then, for the output data described, the expression for $\operatorname{tg} \phi_{n, e q}$ can be written as follows: 


$$
\begin{gathered}
\operatorname{tg} \phi_{n, e q}=\sum_{i=1}^{M}\left(Q_{n, e q, i} / P_{n, e q, i}\right) \cdot w_{P i}= \\
=\frac{474}{800} \cdot 0.552+\frac{237}{400} \cdot 0.276+\frac{129}{250} \cdot 0.172=0.579 .
\end{gathered} .
$$

For the value of the rated power factor of the equivalent $\mathrm{AM}$, the formula is as follows:

$$
\begin{gathered}
\cos \phi_{n, e q}=\left(1+\operatorname{tg}^{2} \phi_{n, e q}\right)^{-1 / 2}= \\
=\left(1+0.579^{2}\right)^{-1 / 2}=0.865 .
\end{gathered}
$$

The active power load factor for an AM, $L F_{i}=P / P_{n}$, in the case of the equivalent $\mathrm{AM}$ is determined according to the following formula:

$$
L F_{e q}=\sum_{i=1}^{M} L F_{i} w_{P_{i}},
$$

where $L F_{e q}$ is the load factor of the equivalent AM, $L F_{i}$ is the load factor of the i-th $\mathrm{AM}, w_{P_{i}}$ is the weighting factor relative to the rated active power of the $\mathrm{i}$-th group of electric motors. The load factor for each AM can be determined according to the ASFMOPC data. To simplify the calculations, let us assume that the load factor for each $\mathrm{AM}$ and of the equivalent $\mathrm{AM}$ is equal to 0.9. The maximum torque $M_{m, e q}$ for the equivalent AM is determined according to the following formula:

$$
\begin{gathered}
M_{m, e q} \approx \sum_{i=1}^{n}\left(M_{m, i} w_{P i}\right)= \\
=2.0 \cdot 0.552+2.1 \cdot 0.276+2.5 \cdot 0.172=2.055 .
\end{gathered}
$$

The motor starting current of the equivalent AM should be equal to the sum of the starting currents of all AMs. That is why the locked rotor current ratio $k_{e q}$ of the equivalent $\mathrm{AM}$ to the rated current of the equivalent $\mathrm{AM}$ is equal to the following:

$$
\begin{gathered}
k_{e q}=\sum_{i=1}^{n}\left(k_{P i} I_{n, i}\right) / I_{n, e q}= \\
=\frac{5.4 \cdot 74.5 \cdot 3+5.1 \cdot 48 \cdot 3+5.8 \cdot 29.4 \cdot 3}{455.7}=5.38 .
\end{gathered} .
$$

When there is no need in providing stability for the AM during long-term supply interruptions $t(t \rightarrow \infty)$, the starting torque of the equivalent $\mathrm{AM} M_{p, e q}$ is determined according to $[10,11]$ in the following way:

$$
\begin{gathered}
M_{p, e q}=\sum_{i=1}^{n}\left(M_{p, i} w_{P, i}\right)= \\
=1.0 \cdot 0.552+1.2 \cdot 0.276+1.3 \cdot 0,172=1.07 .
\end{gathered}
$$

2) A significant number of motors with unknown parameters and working mode are connected to this electrical network node. When used the averaged data for determination of the equivalent AM parameters for a $6 \mathrm{kV}$ load node, its parameters can be expressed by the values specified in $[10,11]$.
Averaged values for $\cos \phi_{n}, M_{m}, M_{p}, k_{e q}$ are taken ) according to column 2 of Table 2; the rated slip $S_{n} \approx 0.02$.

Table 2 compares parameters in the publication (column 3) and the averaged parameters of the equivalent AM (column 2) for a $6 \mathrm{kV}$ load node.

\section{Table 2. Comparison of the calculated and averaged parameters of the equivalent $\mathrm{AM}$ for a $6 \mathrm{kV}$ load node}

\begin{tabular}{|l|c|c|c|}
\hline $\begin{array}{c}\text { Parameters } \\
\text { for equi- } \\
\text { valent AM }\end{array}$ & $\begin{array}{c}\text { Averaged } \\
\text { para- } \\
\text { meters }\end{array}$ & $\begin{array}{c}\text { alculated } \\
\text { para- } \\
\text { meters }\end{array}$ & $\begin{array}{c}\text { Difference in per- } \\
\text { centage terms }(4)=100 \cdot \\
\cdot((3)-(2)) /(3)\end{array}$ \\
\hline $\cos \phi_{n}, \mathrm{RU}$ & 0.84 & 0.865 & 2.90 \\
\hline$M_{m}, \mathrm{RU}$ & 2.20 & 2.055 & -7.05 \\
\hline$M_{p}, \mathrm{RU}$ & 1.40 & 1.070 & -30.80 \\
\hline$k_{e q}, \mathrm{RU}$ & 5.40 & 5.380 & -0.37 \\
\hline
\end{tabular}

The calculation data that are given in column 3 of Table 2 illustrate that the actual equivalent AM parameters in a $6 \mathrm{kV}$ load node significantly differ from their averaged data (the difference being as high as 30\%). That is why when making calculations it is reasonable to use the data obtained by the described method.

Knowing the number of the energized AMs (or SMs) is very helpful when solving one more problem that is, making preparations for the maintenance and repair of electric motors (calculating the run of each motor and its interrepair time).

\section{Conclusions}

1. The developed method for the accurate determination of the equivalent asynchronous motor parameters in real time mode for a load node consisting of several groups of similar AMs is realized by using automatic determination of the number of working AMs in each group. This method increases accuracy while obtaining the equivalent AM parameters (the difference between the calculated and averaged values can be as high as $30 \%$ ).

2. Using the calculated values of the equivalent asynchronous motor parameters increases accuracy when calculating the static and dynamic stability of an industrial undertaking power-supply system, and the nonsinusoidal mode in a network with a higher harmonics source.

3. The data reflecting the number of the energized AM can be used to calculate the run of each motor, and to calculate its interrepair time.

4. The proposed method for determining the number of working motors is preferred when used for the determination of the number of working synchronous motors in each group of the single-type motors, with further determination of the equivalent SM parameters.

\section{REFERENCES}

1. Syromyatnikov, I.A. (1984), Modes of operation of asynchronous and synchronous motors, Energoatomizdat, Moscow, $240 \mathrm{p}$.

2. Gerling, D. (2018), "Dynamic Operation and Control of Induction Machines", Electrical Machines. Mathematical Engineering, Vol. 4, Springer, Berlin, Heidelberg, pp. 325-368, available at: http://dx.doi.org/10.1007/978-3-642-17584-8.12 (last accessed on June 15, 2018). 
3. Gieras, J. F. and Saari J. (2012), "Performance calculation for a high-speed solid-rotor induction motor", IEEE Trans. Ind. Electron., Vol. 59, No. 6, pp. 2689-2700, available at: http://dx.doi.org/10.1109/IECON.2010.5675415 (last accessed on June 15, 2018).

4. Osipov, V.S. (2017), "On the Determination of the Parameters of the Equivalent Circuit of Three-Phase Induction Motors", Russian Electrical Engineering, Vol. 88, No. 12, pp. 845-849, available at: http://dx.doi.org/10.3103/S1068371217120124 (last accessed on June 15, 2018).

5. Ansari, A.A. and Deshpande, D.M. (2010), "Mathematical Model of Asynchronous Machine in MATLAB Simulink", International Journal of Engineering Science and Technology, Vol. 2(5), pp. 1260-1267.

6. Wang, G. and Park, S.W. (2014), "Improved Estimation of Induction Motor Circuit Parameters with Published Motor Performance Data", Sixth Annual IEEE Green Technologies Conference, Corpus Christi, TX, pp. 25-28, available at: http://dx.doi.org/10.1109/GREENTECH.2014.18 (last accessed on June 15, 2018).

7. Gurtovtsev, A.L. (1999), "Integrated automation of energy accounting at industrial enterprises and economic objects", Journal "STA", Vol. 3, pp. 44-45.

8. Gurtovtsev, A.L. (2003), “Automation of power consumption management”, Industrial power engineering, Vol. 8, pp. 5-6.

9. Gurevich, Yu.E., Libov, L.E. and Okin A.A. (1990), Calculations of stability and anti-emergency automatics in power systems, Energoatomizdat, Moscow, 390 p.

10. Gurevich, Yu.E., Libov, L.E. and Okin, A.A. (1981), Load Resistance of Electric Systems, Energoizdat, Moscow, 208 p.

11. Voloshko, A.V. and Bederak, Ya.S. (2016), "Method of automatic determination of the number of simultaneously working in the group of electric motors", Electrical Engineering and Electromechanics, Vol. 5, pp. 61-63, available at: http://dx.doi.org/10.20998/2074-272X.2016.5.10. (last accessed on June 15, 2018).

Надійшла (received) 28.06.2018

Прийнята до друку (accepted for publication) 22.08.2018

\title{
Метод визначення параметрів еквівалентного асинхронного електродвигуна у реальному масштабі часу
}

\author{
Я. С. Бедерак, Д. А. Гапон, А. О. Зуєв
}

Метою досліджень $є$ розробка методу визначення у реальному часі параметрів еквівалентного асинхронного електродвигуна вузла навантаження, що складається 3 декількох груп однотипних асинхронних електродвигунів. Методика. Для проведення розрахунків був розроблений алгоритм, блок-схема якого наведена у публікації. Також наведені розрахункові формули, що враховують вагову долю кожного двигуна та їх групи на основі визначення та аналізу даних електроспоживання, отриманих 3 приладів обліку електроенергії, встановлених на приєднаннях електродвигунів. Результати. Для перевірки придатності розробленого алгоритму наведений розрахунок параметрів еквівалентної машини для вузла, який містить три групи двигунів (800, 400 та 250 кВт), по три двигуни в кожній групі. Практичне значення. Одержані параметри еквівалентного асинхронного електродвигуна можуть бути використані для впровадження автоматизованої оцінки ефективності роботи групи однакових електродвигунів, розрахунків статичної та динамічної стійкості системи електропостачання промислового підприємства, визначення електромагнітної сумісності та захисту від резонансних явищ в мережі з джерелом вищих гармонік. Середнс значення різниці в відсотках між результатами, отриманими запропонованим методом і наявними методиками, становить 5\%, а максимальне сягає $30 \%$. Висновки. Розроблений метод точного визначення еквівалентних параметрів асинхронного двигуна в режимі реального часу для вузла навантаження, що складається з декількох груп аналогічних АЕД, реалізується шляхом автоматичного визначення кількості робочих АЕД в кожній групі. Результати дослідження можуть бути використані для розрахунку ходу кожного двигуна. Пропонований спосіб визначення кількості робочих двигунів $\epsilon$ кращим для визначення числа робочих синхронних двигунів в кожній групі однотипних двигунів.

Ключові слова: еквівалентнй асинхронний електродвигун; група однотипних електродвигунів; вузол навантаження; інформаційно-контрольна система.

Метод определения параметров эквивалентного асинхронного электродвигателя в реальном масштабе времени

$$
\text { Я. С. Бедерак, Д. А. Гапон, А. А. Зуев }
$$

Целью исследований является разработка метода определения в режиме реального времени параметров эквивалентного асинхронного электродвигателя (АЭД) узла нагрузки, состоящего из нескольких групп однотипных асинхронных электродвигателей. Методика. Для проведения расчетов был разработан алгоритм, блок-схема которого приведена в публикации. Также приведены расчетные формулы, учитывающие весовую долю каждого двигателя и их группы, на основе определения и анализа данных электропотребления, полученных с приборов учета электроэнергии, установленных на присоединениях электродвигателей. Результаты. Для проверки эффективности разработанного алгоритма приведен расчет параметров эквивалентной машины для узла, который содержит три группы двигателей (800, 400 и 250 кВТ), по три двигателя в каждой группе. Практическое значение. Полученные параметры эквивалентного асинхронного электродвигателя могут быть использованы для внедрения автоматизированной оценки эффективности работы группы одинаковых электродвигателей, проведения расчетов статической и динамической устойчивости системы электроснабжения промышленного предприятия, оценки электромагнитной совместимости и защиты от резонансных явлений в сети с источником высших гармоник. Среднее значение разности в процентах между результатами, полученными предложенным методом и существующими методиками, составляет 5\%, а максимальное достигает $30 \%$. Выводы. Разработанный метод точного определения эквивалентных параметров асинхронного двигателя в режиме реального времени для узла нагрузки, состоящего из нескольких групп аналогичных АЭД, реализуется путем автоматического определения количества рабочих АЭД в каждой группе. Результаты исследования могут быть использованы для расчета хода каждого двигателя. Предлагаемый способ определения количества рабочих двигателей является предпочтительным для определения числа рабочих синхронных двигателей в группе однотипных двигателей.

Ключевые слова: эквивалентный асинхронный электродвигатель; группа однотипных электродвигателей; узел нагрузки; информационно-управляющая система. 